\title{
Prosociality in Business: A Human Empowerment Framework
}

\author{
Steven A. Brieger ${ }^{1,2} \cdot$ Siri A. Terjesen ${ }^{3,4} \cdot$ Diana M. Hechavarría $^{5} \cdot$ Christian Welzel $^{6,7}$
}

Received: 15 June 2017 / Accepted: 17 October 2018 / Published online: 5 November 2018

(c) The Author(s) 2018

\begin{abstract}
This study introduces a human empowerment framework to better understand why some businesses are more socially oriented than others in their policies and activities. Building on Welzel's theory of emancipation, we argue that human empowerment—comprised of four components: action resources, emancipative values, social movement activity, and civic entitlements-enables, motivates, and entitles individuals to pursue social goals for their businesses. Using a sample of over 15,000 entrepreneurs from 43 countries, we report strong empirical evidence for two ecological effects of the framework components on prosociality. We find that human empowerment (1) lifts entrepreneurs' willingness to choose a social orientation for their business, and (2) reinforces the gender effect on prosociality in business activity. We discuss the human empowerment framework's added value in understanding how modernization processes fully leverage the potential of social business activities for societies.
\end{abstract}

Keywords Social entrepreneurship · Female entrepreneurship · Global entrepreneurship monitor · Culture · Institutions · CSR

Steven A. Brieger

s.a.brieger@sussex.ac.uk

Siri A. Terjesen

terjesen@american.edu

Diana M. Hechavarría

dianah@usf.edu

Christian Welzel

cwelzel@gmail.com

1 Department of Strategy and Marketing, University of Sussex, Brighton BN1 9RH, UK

2 Center for Leadership and Values in Society, University of St.Gallen, 9000 St.Gallen, Switzerland

3 Management Department, American University, 4400 Massachusetts Ave., Washington, DC 20008, USA

4 Norwegian School of Economics, Helleveien 80, 5035 Bergen, Norway

5 Center for Entrepreneurship, Muma College of Business, University of South Florida, 4202 E. Fowler Ave., Tampa, FL 33620, USA

6 Center for the Study of Democracy, Leuphana University of Lüneburg, 21335 Lüneburg, Germany

7 Higher School of Economics, National Research University, Moscow, Russia

\section{Introduction}

Social responsibility is a new paradigm in the business world. An increasing number of businesses extend beyond narrow economic interests to socially responsible practices which contribute to the common good. Compared to any earlier point in history, businesses place importance on improving societal quality of life, social cohesion, and well-being through socially responsible actions (Banerjee 2008; Brammer et al. 2012; Meynhardt et al. 2018). The rise of socially responsible business behavior began in North America and Europe (Beckman et al. 2009), and originates from industrial betterment and welfare movements during Great Britain's industrialization such as the establishment of profit-sharing, lunch rooms, hospital clinics, and other offerings to prevent labor problems and improve performance (Carroll 2008). Among Western societies, individual philanthropy and business philanthropy began to grow in the late 1800 s to improve living conditions and prospects of employees and their families. Businesses' contributions to individuals' welfare were initially voluntary, but are increasingly recognized as essential in order to operate in today's world (ILO 2013a).

The literature increasingly recognizes the vital role that businesses can play in alleviating social problems, improving the common good, and securing sustainable development 
(Montgomery et al. 2012; Santos 2012; Meynhardt and Gomez 2016). Researchers explore the foundations of social orientation, often classifying prosociality in business as a response to increasing problems such as poverty, child and forced labor, global inequality, public over-indebtedness, and government failures such as inadequate provision of public goods and inefficient regulations (Scherer and Palazzo 2011; Kinderman 2012; Blowfield and Murray 2014).

We argue that the phenomenon of socially oriented businesses can also be explained by a profound humanistic transformation of civilization (Inglehart and Welzel 2005; Welzel 2013). Beginning with the Industrial Revolution and accelerating with postindustrial knowledge societies, we witness an ever-growing share of businesses empowered to care about society. This mass-based adoption of socially responsible principles can be linked to a sequence of moral progress of humanity which accelerates as societies climb the stages of human empowerment. Human empowerment gives individuals control over their lives, and motivates these individuals to emphasize equality, tolerance, and free choice and claim their voice to transform humanitarian norms into laws (Welzel 2013).

This study draws on Welzel's (2013) theory of emancipation to develop a human empowerment framework to better understand prosociality in the business world. We assert that four components of human empowerment-action resources, emancipative values, social movement activity, and civic entitlements-enable, motivate, and entitle people to pursue broader social goals with their business. Following the evolutionary logic of Welzel's theory of emancipation, we outline a specific sequence: existential empowerment in terms of higher levels of action resources (which enable a social orientation in doing business) leads to psychological empowerment in terms of higher levels of emancipative values and social movement activity (which motivate a social orientation in doing business) which in turn increases institutional empowerment in terms of civic entitlements (thereby institutionalizing a social orientation in doing business).

Our human empowerment framework proposes two positive 'ecological' effects of the framework components on entrepreneur's prosocial motivations. First, country-level manifestations of the four human empowerment forcesmeasured by a human empowerment index-lift entrepreneurs' willingness to choose a social orientation for their business. Our second step focuses on women's roles in business as women's empowerment is essential for women themselves as well as the development of peace, security, prosperity, sustainability, and democracy (Sen 2001; Klasen 2002; Inglehart and Norris 2003; Hudson et al. 2014; Brieger et al. 2017). In doing this, we hypothesize that human empowerment reinforces the gender effect on prosociality. In a nutshell, we ask the questions: How does human empowerment affect an entrepreneur's prosocial motivation? And how does human empowerment impact the gender effect on prosociality in business?

We empirically test our human empowerment framework with a cross-country dataset of more than 15,000 entrepreneurs from 43 countries. This dataset allows us to examine the extent to which entrepreneurs are willing to follow social objectives in doing business. Socially oriented entrepreneurs are simply called social entrepreneurs, defined as individuals who seek "to create social value through innovativeness, risk management, and pro-activeness bounded by a social mission, sustainability, and the contextual environment" (Lumpkin et al. 2013, p. 763). We view social entrepreneurship as using market-based methods to provide collective goods for a better vision of society (Kickul et al. 2012; Lepoutre et al. 2013).

This study contributes to the literature in a threefold manner: First, by incorporating Welzel's (2013) theory of emancipation to explain how the components of our human empowerment framework elevate prosociality in doing business, we provide a richer theoretical understanding of why businesses are socially oriented in their activities. Second, we complement the debate on the contextual drivers of social entrepreneurship by confirming others' findings that institutional support explains individuals' readiness to pursue social ventures. Finally, we contribute to the discussion on gendered patterns in (social) entrepreneurship by highlighting that compared to men, the level of women's social orientation in doing business is more strongly affected by supportive emancipatory conditions.

\section{A Human Empowerment Framework of Prosociality in Business}

A vast literature explores the role of institutions in shaping economic behavior. According to North (1991), these institutions are humanly devised and comprised both informal (e.g., conventions and codes of behavior) and formal (e.g., laws) which then shape political, economic, and social interactions. These institutional "rules of the game" then govern interactions. Acemoglu and colleagues (2001) describe how fundamental differences in countries' income per capita are driven by institutions, concurring with North and others that countries with "better institutions" will better secure property rights, leading to more investment in human and physical capital and their more efficient use to earn greater incomes. Williamson (2000) highlights that institutions are complex and embedded in cognitive, cultural, structural, and political structures. Institutional scholars concur that a better understanding of institutions can help us understand individual and organizational behavior. One new theoretical framework which links to these ideas is Welzel's (2013) theory 
of emancipation that examines the expansion of a domination-free existence and universal freedoms in humans' lives. According to this theory, human empowerment advances through three elements: action resources which enable individuals to exercise universal freedoms, emancipative values which motivate individuals to pursue universal freedoms, and civic entitlements which guarantee individuals' rights to exercise universal freedoms. The theory of emancipation rests on an evolutionary logic, with two mechanisms: the "utility-valuation" mechanism describes how the spreading of action resources leads to rising emancipative values, and the "value-codification" mechanism accounts for the finding that rising emancipative values lead to expanding civic entitlements.

Welzel argues that all human beings share a universal desire for emancipation and seek a life that is free from domination and external constraints. That is, individuals desire universal freedoms such that they can live according to their own ideas, goals, and visions. The desire for emancipation varies, however, in strength across individuals depending on their resource endowments. Individuals who lack resources and face hard existential conditions are less able to practice freedoms. Since these individuals recognize a low utility of universal freedoms, they do not perceive much use in freedoms. Until quite recently in human history, people struggled with high poverty, low literacy, and short life spans; life was painful, brutish, and short (Deaton 2013; Baldwin 2016). The economic growth process started with industrialization and continues to improve living conditions for billions of people. Indeed, today we enjoy the highest rates of income, literacy rates, and longevity in human history (Deaton 2013; Sachs 2015; Baldwin 2016; Norberg 2016). As an increasing number of individuals gain access to resources and thus the capabilities to handle freedoms, they begin to value these freedoms. As a result, emancipative values grow stronger and subsequently strengthen personal motivation to practice freedoms. Individuals appreciate independent choices and equal opportunities. With strong emancipative values, individuals are more willing to take actions to assert and guarantee these freedoms in form of civic entitlements, which Welzel (2013, p. 13) defines as "guarantees for private and public action, granted equally to all constituents of a society." These guarantees of universal freedoms substantiate this overarching human empowerment process.

Welzel's theory of emancipation follows the idea of moral progress. In reference to the increasing financial security and rising mobilization of education worldwide, people become more open to humanistic moral principles, thus transforming societies towards humanism (Welzel 2013). We believe that this transformation towards human empowerment that makes societies more reflexive, emphatic, and solidary is also reflected in the business world. Individuals' empowerment is thus key to understanding the rise and evolution of prosociality in business including its current and future status.

Since industrialization, many researchers link economic development processes to humans' moral degeneration. For instance, Rousseau's (1920) admiration of the "noble savage" suggests that the golden age of man came before industrialization processes (Friedman 2010). However, while phenomena such as child labor, sweatshop exploitation, corruption, and forced labor are long-standing challenges that must be addressed, working conditions are actually more humane than ever. The International Labour Organization (ILO) documents that the global number of child laborers declined by more than one-third since 2000 , and worldwide labor rights and working conditions continue to improve (ILO 2013b, 2017; Locke et al. 2007; Messenger et al. 2007). Labor standards are increasingly implemented in bilateral and regional free trade agreements (ILO 2013a), and are at their highest level, making workers' lives more enjoyable, interesting, and valuable.

We utilize the theory of emancipation and build a human empowerment framework to explore the role of human empowerment for social business activity. We use Welzel's evolutionary logic to argue that four components of emancipative forces-action resources, emancipative values, social movement activity, and civic entitlements-affect prosociality in doing business. Focusing on entrepreneurs and their social value creation goals, we discuss how the forces of human empowerment impact entrepreneurs' social orientation in their daily business activities. We suggest two 'ecological' effects of human empowerment on prosociality in business activity: First, we hypothesize that the four components of human empowerment jointly lift entrepreneurs' prosociality in doing business such that entrepreneurs tend to be more socially oriented in countries with more prevalent human empowerment forces. Second, we focus on the role of women for prosociality in business. Women harbor strong prosocial values; however, weak emancipatory climates can suppress women's ability and willingness to pursue and express these values, making it thus more difficult for a society to fully leverage its social entrepreneurial potential. Thus, we argue that women's empowerment is key to helping societies achieve the greatest positive impact of social entrepreneurial activity. Figure 1 presents our human empowerment framework of prosociality in business.

\section{The Positive Influence of Human Empowerment on Prosociality in Business}

\section{First Condition: The Abundance of Action Resources}

Action resources describes the abundance of intellectual and material resources which are essential for individuals to exercise control and autonomy over their own lives, create 


\section{HUMAN EMPOWERMENT FRAMEWORK OF PROSOCIALITY IN BUSINESS}

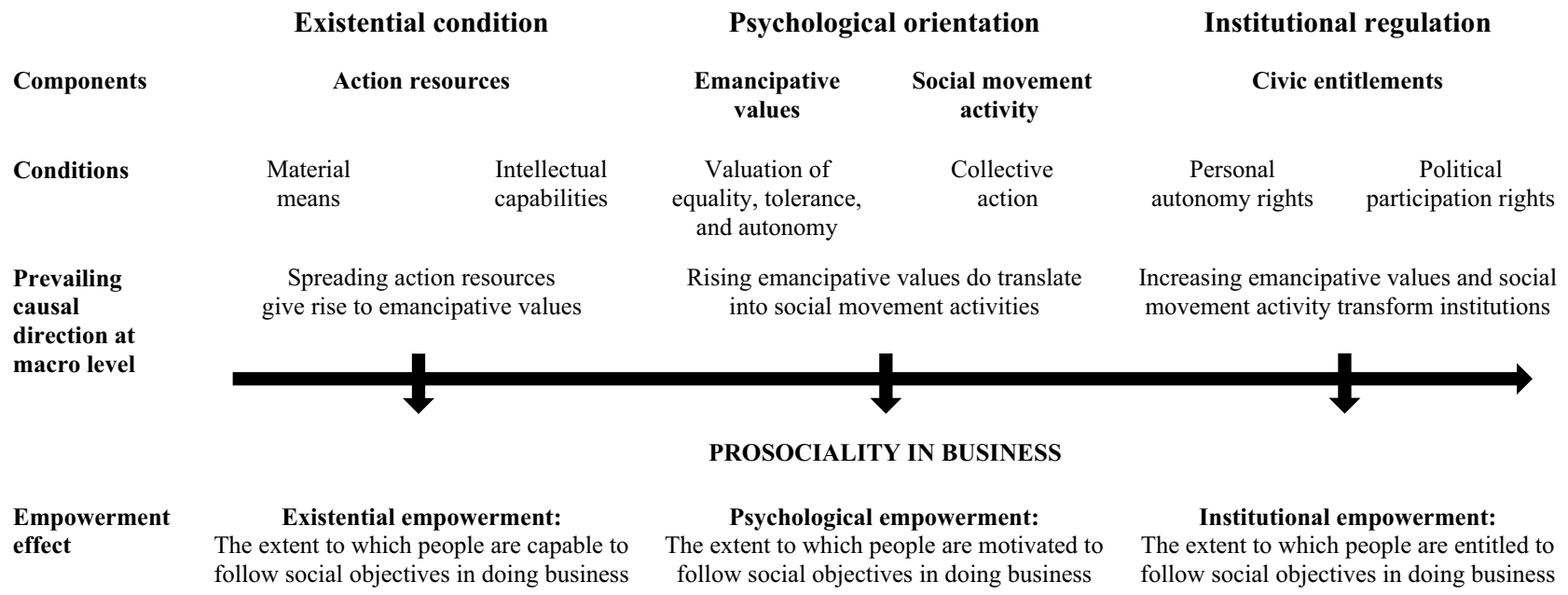

Fig. 1 Human empowerment framework

own individual life plans, and behave according to their values (Welzel 2013; Sen 2001). Action resources are also a prerequisite for prosocial behavior towards society. Individuals with limited material means have narrow care orientations which are mostly confined to their in-groups such as kinship, neighborhoods, and personal contacts. This strong in-group orientation is a natural consequence of existential hardship which makes human beings dependent on in-group solidarity (Triandis 1995; Gelfand et al. 2011). Accordingly, when basic personal needs are unmet, business owners, their customers, and other stakeholders focus more on their very personal needs and in-group ties, placing considerably less emphasis on a wider common good. For instance, customers show a lower willingness to make economic sacrifices for socially responsible products and services when their material resources are restricted (Vermeir and Verbeke 2006). A low demand for social products and services, when material resources are not widespread in the population, should therefore reduce entrepreneurs' social orientation. By contrast, when material resources are available, people can expand their care orientation to out-group members and thus overall social well-being. Therefore, in wealthier nations, individuals are more amenable to reducing their personal standard of living in order to provide more resources to others. Intellectual resources such as education also exert a positive impact on prosociality in business. Education frees individuals from the chains of ignorance, prejudice, and fear, making them more open to others' basic needs (Welzel 2013; Rokeach 1968). Education thus significantly contributes to a universalistic, as opposed to particularistic, care orientation. Also, since individuals with high levels of education are more able to acquire knowledge about businesses' social activities, these individuals will demonstrate greater commitment to socially responsible organizations. Numerous studies find that more educated people hold higher ethical standards, demonstrate greater ethical sensitivity, and consume more ethically than less educated people (Van Liere and Dunlap 1980; Jones and Gautschi 1988; Loe et al. 2000). In line with this evidence, several authors show a positive relationship between an individual's education and social entrepreneurship (Lepoutre et al. 2013; Estrin et al. 2013, 2016; Bosma et al. 2016; Brieger and De Clercq 2018). Taken together, the prevalence of action resources should existentially empower entrepreneurs to choose a social orientation for their business.

\section{Second Condition: The Abundance of Emancipative Values}

An individual may possess action resources to become socially oriented; however, this does not guarantee that this individual will also harbor the motivation to pursue social goals in doing business. We argue that cultural norms in the form of emancipative values drive this orientation. Emancipative values prioritize autonomy, equality, tolerance, and participation, and encourage individuals to be masters of their own lives and to participate in public affairs in the interest of the common good. Emancipative values shape people's mindsets in two ways:

First, the emphasis on equal opportunities inherent in emancipative values comes with an internalization of humanitarian norms; these norms make people sensitive to social justice and more easily upset about its incidence. Second, emancipative values involve an 
appreciation of human self-expression; accordingly, the voicing of shared concerns becomes itself a value thus a source of satisfaction. (Welzel 2013, p. 47)

Emancipative values make societies more humanitarian, civic, ecological, and democratic, and regulate individuals' selfish impulses such that they become more sensitive to injustice (Welzel 2013). Emancipative values will not eradicate individuals' immoral behavior-rather individuals feel a self-regulated pressure to act morally in the interest of the common good.

We suggest that the widespread presence of emancipative values in large population segments motivates various stakeholders-that is, not only entrepreneurs but also customers, employees, suppliers, and others-to become more socially oriented. Entrepreneurs focusing on social problems are committed to humanitarian norms and practices, and wish to contribute to others' well-being through socially responsible business activities. At the same time, a society with stronger emancipative values should appreciate the outcomes of social orientations in the business world. As emancipative values prioritize equality, diversity, and human rights, the products and services of socially oriented entrepreneurs are then more likely to be demanded, valued, and recommended. By contrast, in cultures characterized by weak emancipative values, people are less likely to appreciate equality, diversity, and human rights, and thus social entrepreneurship receives less confirmation and support, and entrepreneurs may be less willing to focus on social issues. Taken together, we expect that entrepreneurs who live in societies characterized by strong emancipative values will feel more secure and encouraged to follow social objectives.

\section{Third Condition: The Abundance of Social Movement Activity}

Social movement activity which is peaceful (e.g., petitions, boycotts, and demonstrations) plays a central role in shaping societies' agendas and is thus a major "manifestation of human empowerment" (Welzel 2013, p. 216). Such movements follow a rise in emancipative values and include individuals pursue goals such as human rights, worker rights, democratic participation, women's equality, children's rights, or environmental protection (Welzel 2013; Welzel and Deutsch 2012). Welzel points out that individuals with stronger emancipative values are more willing to raise their voice, even in high-risk situations. Participation in social movements is thus associated with a vibrant civil society that seeks to create pressure for guarantees that reflect the humanitarian principles of emancipative values.

We argue that peaceful social movement activity can drive prosociality in business. Social movement activity creates a connective and collaborative environment in which human needs are more respected and individuals get involved to voice their claims, thereby seeking to obtain guarantees that are in the interest of the common good. A cultural environment in which people are motivated to voice their claims tend to be associated with actively addressing social goals and needs. Businesses that wish to legitimize themselves and keep their social license to operate must respond to people's articulated wishes regarding emancipatory goals. Prosociality in business is thus also a response to collective pressure (Husted and Allen 2000). Petitions, peaceful demonstrations, and boycotts force organizations to take their social responsibility; for example, 42 percent of the world's leading multinational corporations and 54 percent of top brands face calls for boycotts from potential customers (John and Klein 2003). Thus, social movement activities such as boycotting can develop "devastating effects on sales, corporate reputations, brand images and stock prices" (Balabanis 2013, p. 515). Accordingly, higher levels of social movement activity should motivate entrepreneurs to set social goals in doing business. We argue that courageous social movement activity sends two important signals to socially oriented entrepreneurs which motivate them to follow social objectives. First, social entrepreneurs experience that they are not the only ones who care for the common good; they recognize that there are many others in the civil society who address social needs and interests. Second, individuals who engage in socially oriented business activity will likely find that their environment appreciates this socially responsible business practice.

\section{Fourth Condition: The Abundance of Civic Entitlements}

The second mechanism of the theory of emancipation is institutional empowerment through expanded civic entitlements (Welzel 2013). As emancipative-minded individuals already possess individual assets and are often well connected, they are capable of joining forces (e.g., social movements), voicing their shared desires, and initiating campaign activities to pressure for these desires, which in turn affect institutions. Democracy, including its characteristics such as freedom of expression, separation of powers, rule of law, civic rights, press freedom, associational pluralism, and political self-determination, is the institutional manifestation of people's desires (Welzel 2013). According to Welzel, civic entitlements such as personal autonomy rights (e.g., rule of law, freedom of movement, association, education, speech, expression, and belief) and participation rights (e.g., electoral self-determination, political engagement, and worker rights) form the "core definitional tool of democracy." Civic entitlements permit people to self-govern their private and public lives, and become "autonomous actors who are in the position to recognize and express a 
preference" (Welzel 2013, p. 253) with respect to public or private issues.

Civic entitlements, in the form of citizen rights, play a major role for the prosociality in business such that countries with strong citizen rights guarantee that socially oriented entrepreneurs can express and follow their goals. Moreover, countries in which laws and regulations guarantee citizen rights might better balance out power between business owners and stakeholders such as employees, consumers, and other social groups. Specifically, we expect that in countries with strong worker and participation rights, entrepreneurs will be more likely to focus on social outcomes as government regulations and powerful unions push a stronger social orientation in doing business to benefit employee health, safety, and income (Dawkins 2010; Ioannou and Serafeim 2012). Governmental policies increasingly "institutionalize" social activities in business since these are regarded as important elements of labor governance. Thus, while social engagement was previously voluntary and private, it is now an element of labor regulation (Peels et al. 2016). Moreover, civic entitlements should increase the benefits of social value creation goals by providing incentives to socially oriented businesses in the form of security, property protection, and civil justice. Thus, socially oriented entrepreneurs might become more engaged in social innovation since they have security regarding investments and the exploration of opportunities as well as individual asset allocations (cf. Bowen and De Clercq 2008; Griffiths et al. 2013). This argument is supported by Estrin et al.'s (2013) finding that strong property rights facilitate social entrepreneurial entries. In addition, a society characterized by low corruption, high regulatory quality, and efficient institutions that serve the common good will formally transmit values, preferences, and expectations towards social business. Thus, the abundance of civic entitlements institutionalizes a prosocial orientation in doing business. Taken together, the emancipative forces of human empowerment positively influence the way business men and women adopt social goals for their businesses:

Hypothesis 1 The prosociality in business is higher in countries with greater human empowerment.

\section{The Interplay of Human Empowerment, Gender, and Prosociality in Business}

The literature around the process of human empowerment frequently examines women's emancipation and in particular changes in women's roles once forces of human empowerment begin to grow in a society. Indeed human history's most persistent form of discrimination is women's subordinate role relative to men (Inglehart and Norris 2003; Alexander and Welzel 2011). However, as Alexander and Welzel (2011, p. 364) state, the "progress in women's empowerment has become one of the most forceful global trends." While traditionally women's roles were restricted to home and family care-giving responsibilities, women benefit increasingly from gender-egalitarian conditions today, even in traditional societies as Saudi Arabia. Women's empowerment is essential, not only for women themselves but also for the reinforcement of peace, tolerance, security, prosperity, and sustainability (Sen 2001; Klasen 2002; Inglehart and Norris 2003; Hudson et al. 2014; Brieger et al. 2017).

The positive influence of women on prosocial outcomes is also apparent in the psychology literature which explains women's predisposed prosociality (Jaffee and Hyde 2000; Schwartz and Rubel 2005; Schwartz and Rubel-Lifschitz 2009; Francescato et al. 2017). Evolutionary psychology explains gender differences in social goals by sex-differentiated selection pressures on human ancestors, as well as cognitive and affective mechanisms related to mating and reproduction (Schwartz and Rubel-Lifschitz 2009). In contrast to evolutionary reasoning, social role theory suggests that gender differences in prosocial values reflect gender role beliefs which are driven by the division of labor in society (Wood and Eagly 2002). Within a society, task specialization and sex-typical roles originate from the interaction of physical sex differences (i.e., women's reproductive abilities and men's size and strength) and societal conditions (i.e., local economy, culture, and social structure), which "make certain activities more efficiently performed by one sex or the other" (Eagly and Wood 2011, p. 459). Observations of sex-typical occupational and family roles create the gender stereotypes, norms, and expectations, which are typically characterized as communal for women, that is, friendly, supportive, kind, unselfish, concerned with others' welfare, gentle, and interpersonally sensitive, and agentic for men, that is, assertive, controlling, competitive, and masterful. As social roles are sex-differentiated, society may judge certain roles as only appropriate for only one sex (Eagly 2009). Hence, gender differences in prosocial values can be explained by both sextyped role experiences and gender role expectations.

Women's stronger social orientation, compared to men's, is well-documented in the literature. For instance, a metaanalysis confirms that women consistently score higher than men in care orientation (Jaffee and Hyde 2000). Further literature documents that women, compared to men, are more likely to place importance on benevolence ("preservation and enhancement of the welfare of people with whom one is close") and universalism ("understanding, appreciation, tolerance, and protection for the welfare of all people and nature"); whereas compared to women, men inherently place more value on power ("social status and prestige, control or dominance over people and resources") and achievement ("personal success through demonstrating competence according to social standards") (Schwartz and Rubel-Lifschitz 2009, p. 172). Compared to men, women participate 
more in non-profit sectors and dominate occupations such as social work, nursing, primary teaching, and medical and health management (Themudo 2009). Compared to male entrepreneurs, female entrepreneurs are far more likely to prioritize social venturing goals (Hechavarría et al. 2012, 2017). The gender gap in entrepreneurial activity is smaller among social entrepreneurs than among commercial entrepreneurs, although men are still more likely than women to start social enterprises (Lepoutre et al. 2013). Taken together, this literature suggests that when women are entrepreneurially active, their work tends to have an embedded social purpose:

Hypothesis 2 Females, compared to their male counterparts, have higher levels of prosociality in business.

We further assume an interplay of human empowerment, gender, and prosociality in business. Human empowerment strengthens both genders' prosociality; however, the effect on women should be considerably sharper for two reasons. First, human empowerment facilitates and encourages individuals to pursue and express values that women find inherently more important (cf. Schwartz and Rubel-Lifschitz 2009). Female entrepreneurs who lack existential, psychological, or institutional empowerment cannot pursue their care orientation. For instance, under conditions of financial hardship, female entrepreneurs are more likely supplementary wage earners for their families, and thus less able to behave socially. Also, in cultures characterized by low levels of emancipative values, patriarchal domination may build barriers for out-group solidarity, thereby forcing women to care only for the in-group. Consequently, women are neither allowed to launch their own socially oriented enterprise nor to develop firm strategy according to their own social ideas, values, and goals (cf. Datta and Gailey 2012). Hence, societal conditions characterized by low levels of human empowerment buffer female entrepreneurs' prosociality in business such that women's social orientation will operate at a level below their actual prosocial values.

Second, an environment that supports, appreciates, and encourages prosociality in business, should provide a better "fit" with female entrepreneurs. Person-environment fit theory embodies the premise that individual attitudes, intentions, and behaviors result from an interaction between person and environment (Edwards et al. 2006; Edwards and Shipp 2007). "Fit" refers to the compatibility of individual and his/her environment's characteristics, orientations, and attitudes (Schneider 2001). A person-environment fit can exist when the needs of socially oriented entrepreneurs (e.g., financial security) match the supplies available in the environment (e.g., resources), when the demands of the environment (e.g., contributions to the common good) match with the intentions and behaviors of socially oriented entrepreneurs, or when socially oriented entrepreneurs and the environment share the same strong prosocial values (cf. Edward and Shipp 2007). We expect that such fits affect the readiness of both male and female entrepreneurs to prioritize social goals in the interest of the wider society. As female entrepreneurs tend to have stronger social orientations than men, women should show even stronger positive outcomes on prosociality than men when the society also strongly appreciates and supports prosociality in businessthus creating a larger gender gap in prosociality in business.

Recent research shows that women want to contribute to others' welfare especially when they are embedded in strong emancipatory climates. Schwartz and Rubel-Lifschitz (2009) provide empirical evidence that compared to men, women inherently place greater value on benevolence and universalism in countries where women are empowered, which results in larger gender gaps in prosocial values. Likewise, Costa et al. (2001) report that gender differences in prosocial personality traits are particularly prevalent in countries characterized by an individualist culture, higher wealth and life expectancy of women, and lower fertility rates and illiteracy rates of women. The authors (2001, p. 328) conclude that "gender differences in self-reported personality traits are largest in prosperous and healthy cultures where women have greater educational opportunities." Given our arguments, we expect:

Hypothesis 3 Human empowerment moderates the positive relationship between female and prosociality in business, strengthening the link between females and prosociality in business in the presence of greater human empowerment.

\section{Research Method}

\section{Data Collection}

We use Global Entrepreneurship Monitor's (GEM) Adult Population Survey (APS) data from 2009. GEM measures the antecedents and outcomes of entrepreneurial activity using representative sampling for each country, and is a premier dataset for research on comparative international entrepreneurship (Reynolds et al. 2005; Álvarez et al. 2014; Hörisch et al. 2017). As GEM includes single-item crosssectional measures, GEM is most powerful when combined with other data. GEM is often utilized in multilevel research with other macro-level data (Bosma 2013; Terjesen et al. 2016). We incorporate macro-level data from several sources in the year most proximate to 2009: World Values Survey (WVS), World Bank, Cingranelli-Richards (CIRI) human rights database, and Freedom House (FH).

In 2009, GEM surveyed over 150,000 individuals in over 50 countries (see Lepoutre et al. 2013 for a detailed 
description of the dataset). We follow a broad definition of entrepreneurial activity but restrict our sample to entrepreneurs who own a nascent, new, or established business (Hechavarría et al. 2017; Brieger and De Clercq 2018). Also, we only consider entrepreneurs in working age (18-64 years old). Since the WVS database does not include information for all GEM database countries, our final sample comprises 15,504 entrepreneurs from 43 countries for which complete data are available.

\section{Measures}

\section{Dependent Variable}

Social value creation goals come from GEM and capture entrepreneurs' response for social objectives to the statement: "Organizations may have goals according to the ability to generate economic value, societal value, and environmental value. Please allocate a total of 100 points across these three categories as it pertains to your [venture's] goals." We used the score of points allocated for social value creation goals as our dependent variable.

\section{Independent Variable}

We measure human empowerment with a self-developed Human Empowerment Index, comprised of four human empowerment framework components. This formative multi-item index measures the extent to which people in a country are existentially, psychologically, and institutionally empowered, covering the domains of existential empowerment (action resources), motivational empowerment (emancipative values), behavioral empowerment (social movement activity), and institutional empowerment (civic entitlements). The Human Empowerment Index is calculated at the country level using the $\mathrm{z}$-standardized values of each human empowerment framework component: (action resources + emancipative values + social movement activity + civic entitlements) / 4. Before calculating the index, we ran a factor analysis on the four variables and drew the scree plot to confirm the latent variable is in fact one. The four variables loaded on one factor with factor loadings rang from 0.93 to 0.78 . Cronbach's alpha was 0.83 .

\section{First Framework Component: Action Resources}

We measure action resources with the human development index (HDI), the United Nations Development Program's (UNDP) broad measure of socio-economic development comprising income, education, and longevity data. The data come from the year 2008 .

\section{Second Framework Component: Emancipative Values}

Emancipative values is a 12 -item index which measures each individual's belief in freedom of choice and equal opportunities by four values dimensions: (a) gender values: an orientation that prioritizes gender equality over patriarchy, (b) autonomy values: an orientation that prioritizes self-determination over obedience, (c) liberty values: an orientation that prioritizes reproductive freedoms over their restriction, and (d) expression values: an orientation that prioritizes voice over order (for a detailed description see Welzel 2013, pp. 75-104). Each orientation consists of three single items from the WVS. Gender values include the propositions: "education is more important for a boy than a girl," "when jobs are scarce, men should have priority over women to get a job," and "men are better political leaders than women." Autonomy values measured the extent to which each respondent evaluates desirable qualities of children as imagination and independence, and not obedience. Liberty values examine each individual's extent of reproductive choices regarding child birth (abortion), cohabitation (divorce), and sexual orientation (homosexuality). Expression values explore each individual's priority to have a say "in important government decisions," "in how things are done at their jobs and in their communities," and on "protecting freedom of speech." We normalized the 12 emancipative values into a scale range with minimum 0 for least emancipative and maximum 1 for most emancipative and then averaged the emancipative values into the four sub-indices. Finally, the sub-indices were added up and divided by four, yielding an overall multi-point index of emancipative values. Each country's data are collected either in 2009 (the year of our dependent variable) or earlier. When data in a country have not been collected before 2009, we use newer data most proximate to the year 2009 .

\section{Third Framework Component: Social Movement Activity}

Social movement activity is a 3 -item index measuring the extent that a country's culture includes three types of peaceful social movement activities: (1) "signing petitions," (2) "attending peaceful demonstrations," and (3) "joining in boycotts." For each country, we calculate the average over the three peaceful social movement activities on the $0-1$ index (for a detailed description see Welzel 2013, pp. 222-225). We use each country's data from 2009 or earlier; or if unavailable earlier, the most proximate to the year 2009. 


\section{Fourth Framework Component: Civic Entitlements}

Institutional opportunities consider two variables: citizen rights and good governance. Citizen rights is an index covering political participation rights and a personal autonomy rights, and encompasses three steps (for a detailed description see Welzel 2013, pp. 259-263). As a first step, we create an index of participation rights using rescaled versions of political rights ratings by Freedom House (FH) and Cingranelli-Richards (CIRI) empowerment rights. This index "measures the scope of legally granted and practically respected participation rights" (Welzel 2013, p. 262). There are three categories of FH political rights: electoral process, political pluralism and participation, and functioning of government which sum ten indicators (Freedom House 2012). CIRI empowerment rights are based on five indicators: freedom of movement, freedom of speech, worker's rights, political participation, and freedom of religion. In the second step, we combine rescaled versions of FH civil liberties and CIRI integrity rights into an additive index of personal autonomy rights which reflects the extent to which autonomous rights are respected and legally granted (Welzel 2013, p. 262). There are four categories of FH civil liberties: freedom of expression and belief, personal autonomy and individual rights, rule of law, and associational and organizational rights, consisting of 15 indicators. The third step multiplicatively combines the political participation rights index and the personal autonomy rights index due to their mutual dependency (Welzel 2013, p. 259). The citizen rights index ranges from 0 for the full non-existence of citizen rights in law and practice to 1 for the full existence of citizen rights in law and practice. The data come from the year 2008.

\section{Control Variables}

We follow prior entrepreneurship research in including additional individual entrepreneur variables: respondent's gender, age, income, education, personal trait characteristics such as knowing an entrepreneur, having start-up skills, having fear of failure, entrepreneurial stage, and household size (Bosma 2013). We code female $=1$ and male $=0$. Age is a continuous variable. Household income is divided into three categories (lower 33\%; middle 33\%; upper 33\%) based on each country's income distribution. Education captures each respondent's highest educational level from $1=$ "no formal education" to $5=$ "graduate experience." Start-up skills are measured by a response to "you have the knowledge, skill and experience required to start a new business" $(1=$ yes, $0=$ no). Fear of failure is measured by a response to "fear of failure would prevent you from starting a business" ( $1=$ yes, $0=$ no). Finally, knows entrepreneur captures a response to the statement: "you know someone personally who started a business in the past 2 years?" $(1=$ yes, $0=$ no). We control for household size because the number of household members might influence an entrepreneur's decision to pursue social objectives. This variable contains five categories, ranging from 1 for one household member to 5 when five or more members live in the household. Nascent entrepreneur is a binary variable $=1$ if the entrepreneur is actively involved in start-up efforts in the past 12 months, expects to own a share of the business he or she is starting, and has not received wages or salaries for more than three months, and $=0$ otherwise.

\section{Data Analysis}

Level 1 data (individuals) are nested in level 2 (countries), so we employ a linear multilevel regression which is preferable to traditional multiple regression techniques which are susceptible to biased standard errors for estimations on the level due to the nested data. In contrast to traditional regression, multilevel modeling recognizes the hierarchical structures and estimates the dependent variable's differences among and within countries (Hox 2010). Multilevel modeling is appropriate when significant variance in dependent variables exists between countries. To check the variance in the dependent variable, we first compute the intraclass correlation coefficient of a null model (or intercept only model) for social value creation goals. The ICC of 0.131 reveals that roughly 13 percent of the variance in social value creation goals lies between countries. Multilevel modeling is recommended if ICC values are 0.10 or larger. ICC values of 0.10 to 0.15 represent medium to large sizes in organizational research (Hox 2010). The specified integrated two-level models include random intercepts and a random slope for the gender variable. All explanatory variables are z-standardized to directly compare each variable's relative impact on social value creation goals and the interpretation of both main and interaction effects.

\section{Results}

Tables 1 and 2 provide descriptive statistics and a correlation matrix. The results provide initial evidence that human empowerment encourages prosociality in business. We find significant, positive bivariate relationships between entrepreneurs' social value creation goals and human empowerment $(r=0.17 ; p<0.01)$. Furthermore, women entrepreneurs are more likely to prioritize social goals for their ventures than do men $(r=0.04 ; p<0.01)$.

Table 3 contains the results of the multilevel regression models used to test Hypothesis 1. Table 3's Model 1 presents the base model that only includes the independent variables at the individual level. Model 1 results show that the 
Table 1 Descriptive statistics

\begin{tabular}{lrrrll}
\hline Variable & $N$ & Mean & SD & Min & Max \\
\hline Social value creation goals & 15,504 & 20.810 & 18.960 & 0 & 100 \\
Female & 15,504 & 0.384 & 0.486 & 0 & 1 \\
Age & 15,504 & 40.905 & 11.867 & 18 & 64 \\
Household income & 15,504 & 1.367 & 0.764 & 0 & 2 \\
Education & 15,504 & 1.937 & 1.074 & 0 & 4 \\
Household size & 15,504 & 3.508 & 1.255 & 1 & 5 \\
Start-up skills & 15,504 & 0.838 & 0.368 & 0 & 1 \\
Fear of failure & 15,504 & 0.287 & 0.453 & 0 & 1 \\
Knows entrepreneur & 15,504 & 0.579 & 0.494 & 0 & 1 \\
Nascent entrepreneur & 15,504 & 0.299 & 0.458 & 0 & 1 \\
Human empowerment & 43 & 0.522 & 0.151 & 0.226 & 0.770 \\
Action resources & 43 & 0.779 & 0.114 & 0.458 & 0.937 \\
Emancipative values & 43 & 0.465 & 0.108 & 0.216 & 0.723 \\
Social movement activity & 43 & 0.295 & 0.126 & 0.059 & 0.520 \\
Civic entitlements & 43 & 0.548 & 0.318 & 0.000 & 1.000 \\
\hline
\end{tabular}

variables female $(\beta=1.159 ; p<0.01)$, household income $(\beta$ $=-0.328 ; p<0.05)$, education $(\beta=1.340 ; p<0.01)$, household size $(\beta=-0.410 ; p<0.01)$, fear of failure $(\beta=-0.347$; $p<0.05)$, and nascent entrepreneur $(\beta=1.351 ; p<0.01)$ are significantly associated with prosociality in business. Model 2 adds the human empowerment measure that combines the four single human empowerment forces. Model 2 findings provide empirical support for Hypothesis 1: there is a significant, positive effect of human empowerment on social value creation goals. In other words, a country's prevalence of combined action resources, emancipative values, social movement activity, and civic entitlements is positively related to prosociality in business $(\beta=3.225 ; p<0.01)$. To check our results' robustness, we also employ the single human empowerment measures as independent variables in Models 3 to 6 . The results show that country-level manifestations of action resources $(\beta=2.523 ; p<0.05)$, emancipative values $(\beta=2.656 ; p<0.01)$, social movement activity $(\beta=2.608 ; p<0.01)$, and civic entitlements $(\beta=2.514$; $p<0.05)$ are positively associated with entrepreneurs' prosociality in doing business. The combined effect is stronger than the single empowerment force effects.

We also find support for Hypotheses 2 and 3. Model 1 reveals a positive relationship between female and social value creation goals $(\beta=1.159 ; p<0.01)$, indicating that women are more likely to start and run a socially oriented venture than do men. Furthermore, Models 7 to 11 of Table 4 provide evidence that women entrepreneurs are, compared to men, more socially oriented with their businesses in emancipatory climates. Compared to male entrepreneurs, women entrepreneurs report even higher degrees of venture social orientation when they live in countries characterized by strong human empowerment $(\beta=1.106 ; p<0.01)$. The significant interaction terms between gender and the single components of human empowerment also show the robustness of this pattern.

To better understand the main and interaction effects, we plot the corresponding graphs. Figure 2 shows that the impact of human empowerment coincides with the average reported social value goals across all countries represented in our sample. We identify a linear trend in our model: as human empowerment increases, prosociality in business also increases. Figure 3 illustrates the interaction between gender and the human empowerment measure. Regarding Fig. 3, weak and strong stand for one standard deviation below or above the mean. The positive relationship between social value creation goals and female gender is stronger when a female entrepreneur is embedded in climates with more abundant action resources, emancipative values, social movement activity, and civic entitlements.

\section{Discussion and Conclusion}

\section{Discussion of Findings}

This study outlines and tests a human empowerment framework to explore why and how the emancipative forces of human empowerment positively influence prosociality in business. We argue that the rise of prosociality in business can be explained by a profound humanistic transformation of civilization (Welzel 2013; Inglehart and Welzel 2005), suggesting that mass-based adoption of socially responsible principles is linked to a sequence of moral progress of humanity which accelerates as societies climb the stages of human empowerment (Welzel 2013). We develop a comprehensive theoretical and conceptual model which incorporates country-level conditions under which individuals are more likely to follow social objectives in doing business. Following the evolutionary logic of Welzel's theory of emancipation, we transpose the sequential components of the framework into a cross-sectional combination of elements: existential empowerment in terms of higher levels of action resources (which enable a social orientation in doing business) leads to psychological empowerment in terms of higher levels of emancipative values and social movement activity (which motivate a social orientation in doing business), which in turn increases institutional empowerment in terms of civic entitlements (which institutionalize a social orientation in doing business). We test our framework with data from more than 15,000 entrepreneurs located in 43 countries. Social entrepreneurship is a suitable context in which to explore prosociality given the burgeoning attention of scholarship at the intersection of ethics and entrepreneurship (Bacq and Eddleston 2018; Cater et al. 2017; Dey and Lehner 2017; Fowler et al. 2017). 


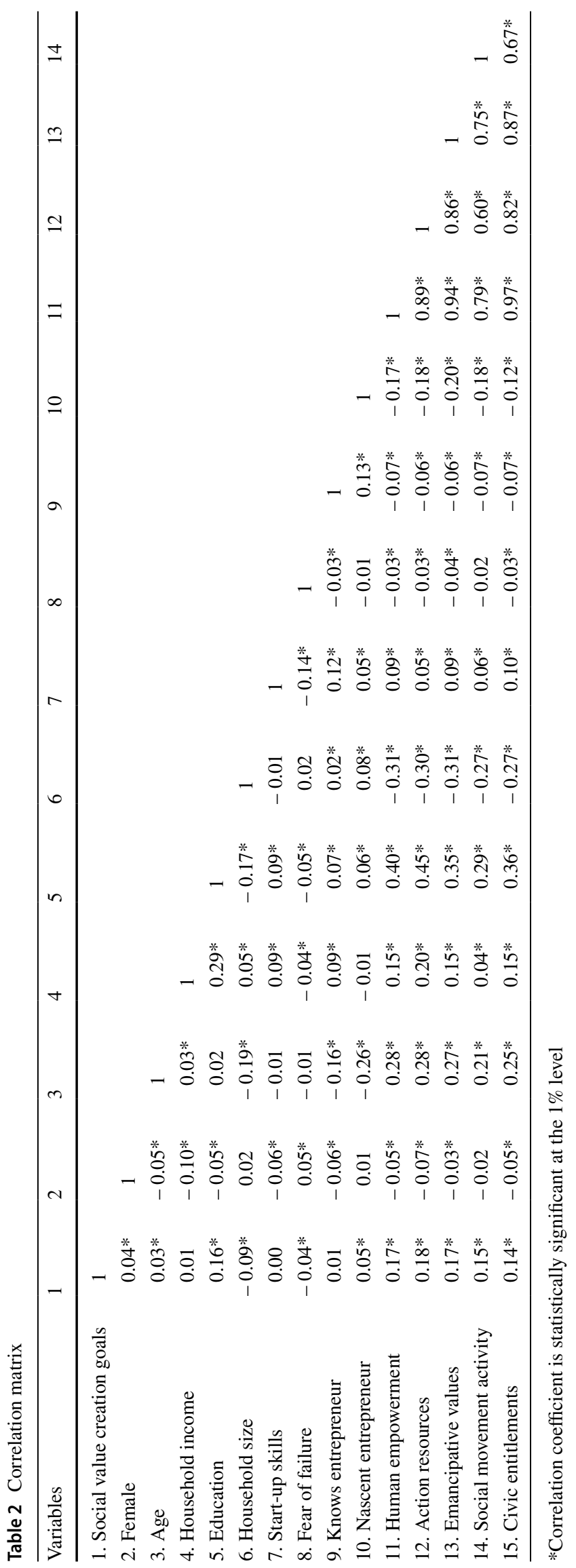


Table 3 Multilevel regression results for social value creation goals

\begin{tabular}{|c|c|c|c|c|c|c|}
\hline & Model 1 & Model 2 & Model 3 & Model 4 & Model 5 & Model 6 \\
\hline Constant & $\begin{array}{l}21.351^{* * *} \\
(1.048)\end{array}$ & $\begin{array}{l}21.280 * * * \\
(0.953)\end{array}$ & $\begin{array}{l}21.139 * * * \\
(0.990)\end{array}$ & $\begin{array}{l}21.366^{* * * *} \\
(0.965)\end{array}$ & $\begin{array}{l}21.361 * * * \\
(0.957)\end{array}$ & $\begin{array}{l}21.318 * * * \\
(0.982)\end{array}$ \\
\hline \multicolumn{7}{|l|}{ Individual-level effects } \\
\hline Female & $\begin{array}{l}1.159 * * * \\
(0.269)\end{array}$ & $\begin{array}{l}1.156 * * * \\
(0.269)\end{array}$ & $\begin{array}{l}1.159 * * * \\
(0.269)\end{array}$ & $\begin{array}{l}1.155^{* * * *} \\
(0.269)\end{array}$ & $\begin{array}{l}1.157 * * * \\
(0.268)\end{array}$ & $\begin{array}{l}1.157 * * * \\
(0.269)\end{array}$ \\
\hline Age & $\begin{array}{l}0.043 \\
(0.156)\end{array}$ & $\begin{array}{l}0.029 \\
(0.156)\end{array}$ & $\begin{array}{l}0.032 \\
(0.156)\end{array}$ & $\begin{array}{l}0.031 \\
(0.156)\end{array}$ & $\begin{array}{l}0.033 \\
(0.156)\end{array}$ & $\begin{array}{l}0.032 \\
(0.156)\end{array}$ \\
\hline Household income & $\begin{array}{l}-0.328^{* *} \\
(0.156)\end{array}$ & $\begin{array}{l}-0.329^{* *} \\
(0.156)\end{array}$ & $\begin{array}{l}-0.329 * * \\
(0.156)\end{array}$ & $\begin{array}{l}-0.329^{* *} \\
(0.156)\end{array}$ & $\begin{array}{l}-0.326^{* *} \\
(0.156)\end{array}$ & $\begin{array}{l}-0.329 * * \\
(0.156)\end{array}$ \\
\hline Education & $\begin{array}{l}1.340 * * * \\
(0.176)\end{array}$ & $\begin{array}{l}1.313 * * * \\
(0.176)\end{array}$ & $\begin{array}{l}1.315^{* * * *} \\
(0.176)\end{array}$ & $\begin{array}{l}1.321 * * * \\
(0.176)\end{array}$ & $\begin{array}{l}1.321 * * * \\
(0.176)\end{array}$ & $\begin{array}{l}1.322 * * * \\
(0.176)\end{array}$ \\
\hline Household size & $\begin{array}{l}-0.410 * * * \\
(0.155)\end{array}$ & $\begin{array}{l}-0.391 * * \\
(0.155)\end{array}$ & $\begin{array}{l}-0.397 * * \\
(0.155)\end{array}$ & $\begin{array}{l}-0.393^{* *} \\
(0.155)\end{array}$ & $\begin{array}{l}-0.394 * * \\
(0.155)\end{array}$ & $\begin{array}{l}-0.396 * * \\
(0.155)\end{array}$ \\
\hline Start-up skills & $\begin{array}{c}-0.208 \\
(0.151)\end{array}$ & $\begin{array}{c}-0.208 \\
(0.151)\end{array}$ & $\begin{array}{l}-0.207 \\
(0.151)\end{array}$ & $\begin{array}{l}-0.209 \\
(0.151)\end{array}$ & $\begin{array}{c}-0.208 \\
(0.151)\end{array}$ & $\begin{array}{c}-0.209 \\
(0.151)\end{array}$ \\
\hline Fear of failure & $\begin{array}{l}-0.347 * * \\
(0.146)\end{array}$ & $\begin{array}{l}-0.347 * * \\
(0.146)\end{array}$ & $\begin{array}{l}-0.348 * * \\
(0.146)\end{array}$ & $\begin{array}{l}-0.346^{* *} \\
(0.146)\end{array}$ & $\begin{array}{l}-0.348^{* *} \\
(0.146)\end{array}$ & $\begin{array}{l}-0.347 * * \\
(0.146)\end{array}$ \\
\hline Knows entrepreneur & $\begin{array}{l}0.121 \\
(0.151)\end{array}$ & $\begin{array}{l}0.123 \\
(0.151)\end{array}$ & $\begin{array}{l}0.122 \\
(0.151)\end{array}$ & $\begin{array}{l}0.122 \\
(0.151)\end{array}$ & $\begin{array}{l}0.123 \\
(0.151)\end{array}$ & $\begin{array}{l}0.123 \\
(0.151)\end{array}$ \\
\hline Nascent entrepreneur & $\begin{array}{l}1.351 * * * \\
(0.162)\end{array}$ & $\begin{array}{l}1.363 * * * \\
(0.162)\end{array}$ & $\begin{array}{l}1.360 * * * \\
(0.162)\end{array}$ & $\begin{array}{l}1.361 * * * \\
(0.162)\end{array}$ & $\begin{array}{l}1.361 * * * \\
(0.162)\end{array}$ & $\begin{array}{l}1.358 * * * \\
(0.162)\end{array}$ \\
\hline \multicolumn{7}{|l|}{ Country-level effects } \\
\hline Human empowerment & & $\begin{array}{l}3.225 * * * \\
(1.091)\end{array}$ & & & & \\
\hline Action resources & & & $\begin{array}{l}2.523 * * \\
(1.117)\end{array}$ & & & \\
\hline Emancipative values & & & & $\begin{array}{l}2.656 * * * \\
(0.977)\end{array}$ & & \\
\hline Social movement activity & & & & & $\begin{array}{l}2.608 * * * \\
(0.898)\end{array}$ & \\
\hline Civic entitlements & & & & & & $\begin{array}{l}2.514 * * \\
(1.022)\end{array}$ \\
\hline ICC & 0.127 & 0.107 & 0.114 & 0.109 & 0.108 & 0.113 \\
\hline Individual-level variance & $311.95 * * *$ & $311.95 * * *$ & $311.96 * * *$ & $311.95 * * *$ & $311.95^{* * *}$ & $311.95 * * *$ \\
\hline Country-level variance & $45.48 * * *$ & $37.23 * * *$ & $39.98 * * *$ & $38.27 * * *$ & $37.63 * * *$ & $39.68 * * *$ \\
\hline Log likelihood & -66616.1 & -66612.2 & -66613.7 & -66612.7 & -66612.3 & -66613.3 \\
\hline AIC & 133258.2 & 133252.3 & 133255.5 & 133253.5 & 133252.5 & 133254.6 \\
\hline $\mathrm{BIC}$ & 133357.7 & 133359.4 & 133362.6 & 133360.5 & 133359.6 & 133361.7 \\
\hline LR test vs. linear model & $1422.1 * * *$ & $1170.4^{* * *}$ & $1181.2 * * *$ & $1174.0 * * *$ & $1236.5^{* * *}$ & $1304.3^{* * *}$ \\
\hline
\end{tabular}

Sign. levels: $* p<0.1 ; * *<0.05 ; * * * p<0.01$. The sample includes 43 countries $(N=15,504)$

Human empowerment $=($ Action resources + Emancipative values + Social movement activity + Civic entitlements) / 4
We examine two ecological effects in two steps: In a first step, we show that the four human empowerment components-action resources, emancipative values, social movement activity, and civic entitlements-jointly lift entrepreneurs' inclination to adopt a social orientation for their business. Our results indicate that prosociality in business is an outcome of advantageous conditions. When entrepreneurs or their customers live under conditions of financial hardship, they are more economically oriented to care for their own personal needs and those of their in-group members, e.g., family. They are thus less likely to both care for the common good and prioritize social 
Table 4 Multilevel regression results for social value creation goals

\begin{tabular}{|c|c|c|c|c|c|}
\hline & Model 7 & Model 8 & Model 9 & Model 10 & Model 11 \\
\hline Constant & $\begin{array}{l}21.268^{* * *} \\
(0.949)\end{array}$ & $\begin{array}{l}21.142 * * * \\
(0.987)\end{array}$ & $\begin{array}{l}21.345^{* * *} \\
(0.961)\end{array}$ & $\begin{array}{l}21.347 * * * \\
(0.956)\end{array}$ & $\begin{array}{l}21.312 * * * \\
(0.979)\end{array}$ \\
\hline \multicolumn{6}{|l|}{ Individual-level effects } \\
\hline Female & $\begin{array}{l}1.120^{* * *} \\
(0.219)\end{array}$ & $\begin{array}{l}1.117 * * * \\
(0.230)\end{array}$ & $\begin{array}{l}1.131 * * * \\
(0.227)\end{array}$ & $\begin{array}{l}1.124 * * * \\
(0.216)\end{array}$ & $\begin{array}{l}1.130^{* * *} \\
(0.239)\end{array}$ \\
\hline Age & $\begin{array}{l}0.023 \\
(0.156)\end{array}$ & $\begin{array}{l}0.025 \\
(0.156)\end{array}$ & $\begin{array}{l}0.027 \\
(0.156)\end{array}$ & $\begin{array}{l}0.030 \\
(0.156)\end{array}$ & $\begin{array}{l}0.028 \\
(0.156)\end{array}$ \\
\hline Household income & $\begin{array}{l}-0.326^{* * *} \\
(0.156)\end{array}$ & $\begin{array}{l}-0.326^{* *} \\
(0.156)\end{array}$ & $\begin{array}{l}-0.328^{* *} \\
(0.156)\end{array}$ & $\begin{array}{l}-0.325 * * \\
(0.156)\end{array}$ & $\begin{array}{l}-0.326 * * \\
(0.156)\end{array}$ \\
\hline Education & $\begin{array}{l}1.301^{* * *} \\
(0.176)\end{array}$ & $\begin{array}{l}1.304 * * * \\
(0.176)\end{array}$ & $\begin{array}{l}1.311^{* * *} \\
(0.176)\end{array}$ & $\begin{array}{l}1.313 * * * \\
(0.176)\end{array}$ & $\begin{array}{l}1.316^{* * * *} \\
(0.176)\end{array}$ \\
\hline Household size & $\begin{array}{l}-0.396 * * \\
(0.155)\end{array}$ & $\begin{array}{l}-0.403 * * * \\
(0.155)\end{array}$ & $\begin{array}{l}-0.396^{* *} \\
(0.155)\end{array}$ & $\begin{array}{l}-0.397 * * \\
(0.155)\end{array}$ & $\begin{array}{l}-0.400^{* * * *} \\
(0.155)\end{array}$ \\
\hline Start-up skills & $\begin{array}{l}-0.196 \\
(0.151)\end{array}$ & $\begin{array}{l}-0.195 \\
(0.151)\end{array}$ & $\begin{array}{l}-0.200 \\
(0.151)\end{array}$ & $\begin{array}{l}-0.199 \\
(0.151)\end{array}$ & $\begin{array}{l}-0.201 \\
(0.151)\end{array}$ \\
\hline Fear of failure & $\begin{array}{l}-0.349 * * \\
(0.146)\end{array}$ & $\begin{array}{l}-0.350^{* *} \\
(0.146)\end{array}$ & $\begin{array}{l}-0.347 * * \\
(0.146)\end{array}$ & $\begin{array}{l}-0.350^{* *} \\
(0.146)\end{array}$ & $\begin{array}{l}-0.346 * * \\
(0.146)\end{array}$ \\
\hline Knows entrepreneur & $\begin{array}{l}0.129 \\
(0.151)\end{array}$ & $\begin{array}{l}0.124 \\
(0.151)\end{array}$ & $\begin{array}{l}0.130 \\
(0.151)\end{array}$ & $\begin{array}{l}0.125 \\
(0.151)\end{array}$ & $\begin{array}{l}0.128 \\
(0.151)\end{array}$ \\
\hline Nascent entrepreneur & $\begin{array}{l}1.368^{* * * *} \\
(0.162)\end{array}$ & $\begin{array}{l}1.360^{* * * *} \\
(0.162)\end{array}$ & $\begin{array}{l}1.367 * * * \\
(0.162)\end{array}$ & $\begin{array}{l}1.368 * * * \\
(0.162)\end{array}$ & $\begin{array}{l}1.362 * * * \\
(0.162)\end{array}$ \\
\hline \multicolumn{6}{|l|}{ Country-level effects } \\
\hline Human empowerment & $\begin{array}{l}3.288^{* * *} \\
(1.086)\end{array}$ & & & & \\
\hline Action resources & & $\begin{array}{l}2.546^{* *} \\
(1.113)\end{array}$ & & & \\
\hline Emancipative values & & & $\begin{array}{l}2.718 * * * \\
(0.974)\end{array}$ & & \\
\hline Social movement activity & & & & $\begin{array}{l}2.664 * * * \\
(0.897)\end{array}$ & \\
\hline Civic entitlements & & & & & $\begin{array}{l}2.553 * * \\
(1.019)\end{array}$ \\
\hline \multicolumn{6}{|l|}{ Cross-level effects } \\
\hline $\begin{array}{l}\text { Female } \\
\times \text { Human empowerment }\end{array}$ & $\begin{array}{l}1.106^{* * * *} \\
(0.244)\end{array}$ & & & & \\
\hline$\times$ Action resources & & $\begin{array}{l}0.948^{* * * *} \\
(0.240)\end{array}$ & & & \\
\hline$\times$ Emancipative values & & & $\begin{array}{l}0.916^{* * *} \\
(0.226)\end{array}$ & & \\
\hline$\times$ Social movement activity & & & & $\begin{array}{l}0.945^{* * * *} \\
(0.209)\end{array}$ & \\
\hline$\times$ Civic entitlements & & & & & $\begin{array}{l}0.768^{* * *} \\
(0.247)\end{array}$ \\
\hline ICC & 0.106 & 0.113 & 0.109 & 0.107 & 0.112 \\
\hline Individual-level variance & $311.94 * * *$ & $311.93 * * *$ & $311.94 * * *$ & $311.96^{* * *}$ & $311.96^{* * * *}$ \\
\hline Country-level variance & $36.92 * * *$ & $39.71 * * *$ & $37.97 * * *$ & $37.53 * * *$ & $39.42 * * *$ \\
\hline Log likelihood & -66604.0 & -66607.1 & -66605.9 & -66604.4 & -66609.1 \\
\hline AIC & 133238.0 & 133244.2 & 133241.8 & 133238.8 & 133248.2 \\
\hline $\mathrm{BIC}$ & 133352.7 & 133358.9 & 133356.5 & 133353.5 & 133362.9 \\
\hline LR test vs. linear model & $1148.5^{* * * *}$ & $1167.1 * * *$ & $1150.3 * * *$ & $1215.4 * * *$ & $1291.1^{* * * *}$ \\
\hline
\end{tabular}

Sign. levels: $* p<0.1 ; * *<<0.05 ; * * * p<0.01$. Sample includes 43 countries $(N=15,504)$

Human empowerment $=($ Action resources + Emancipative values + Social movement activity + Civic entitlements) / 4 


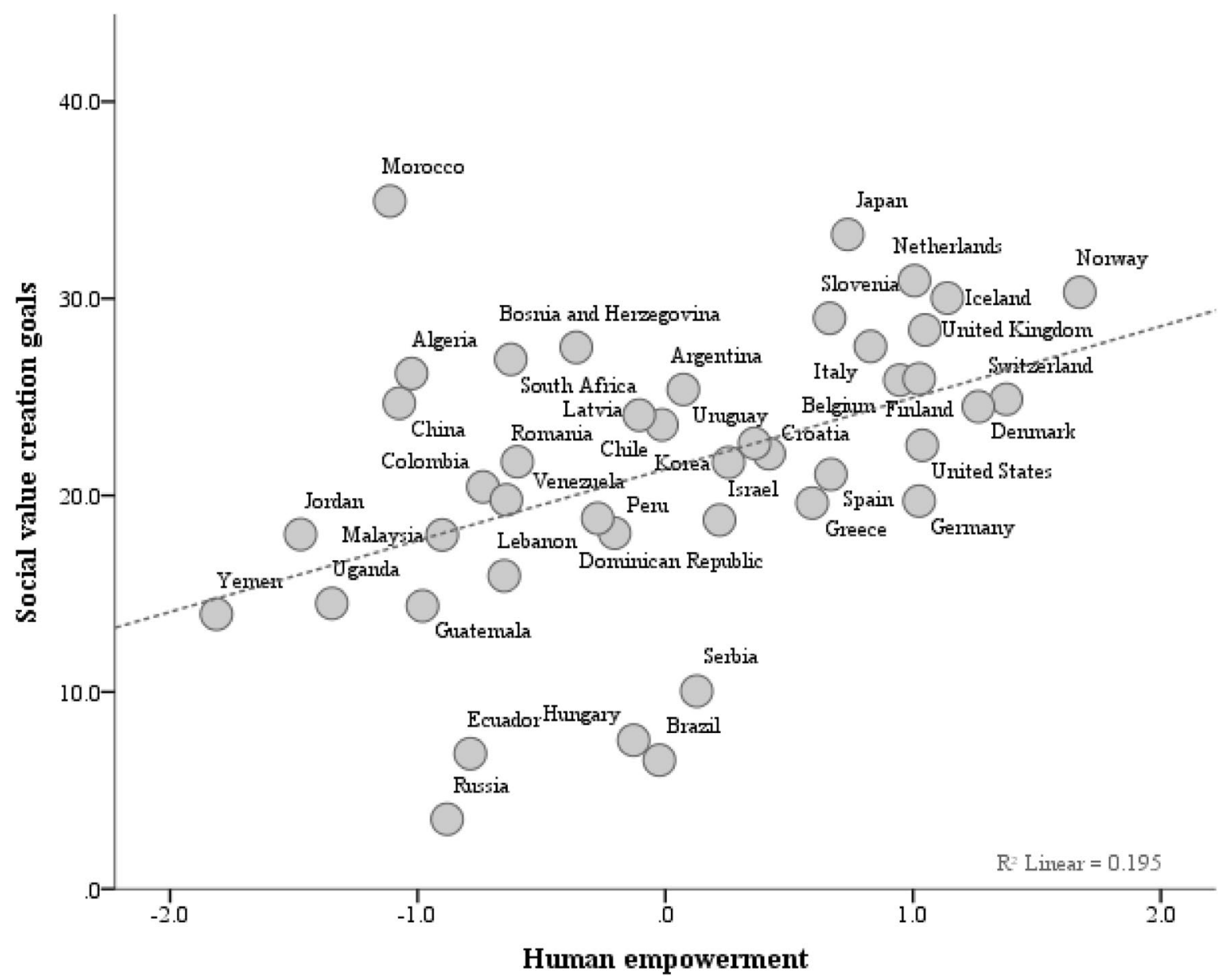

Fig. 2 Relationship between prosociality in business and human empowerment

Fig. 3 Interplay of human empowerment, gender, and prosociality in business

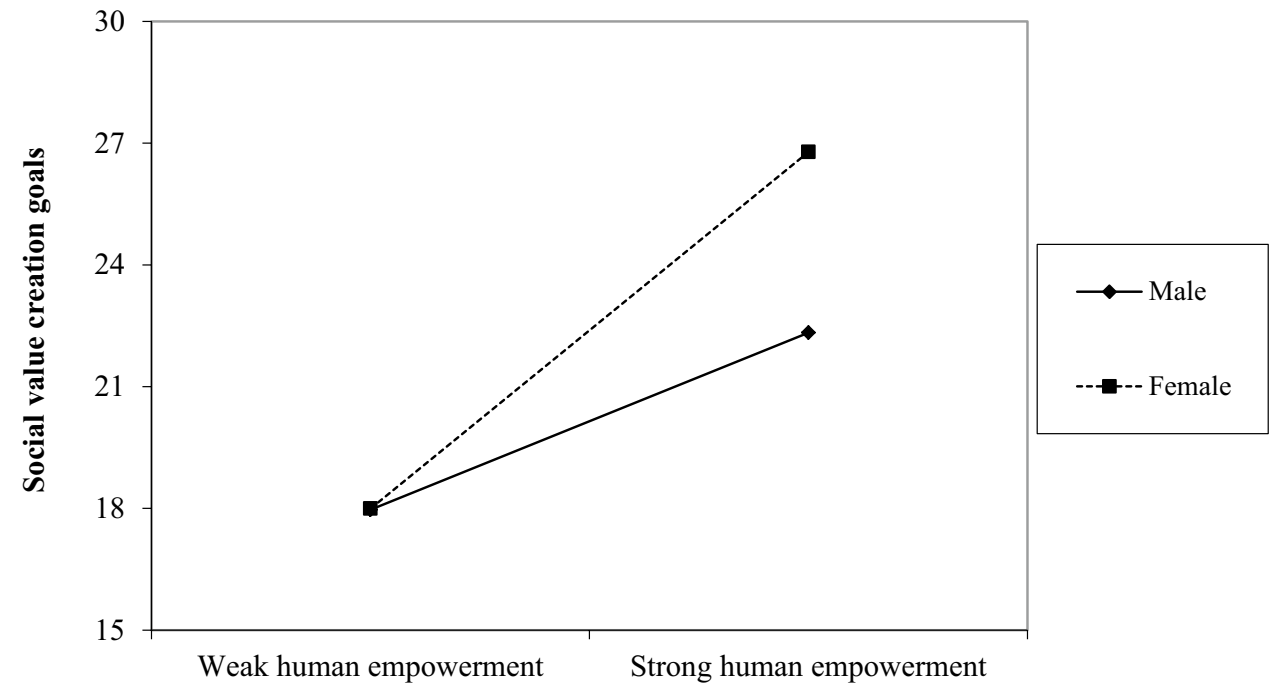

responsibility. A population's education level positively influences prosociality in business since education makes people more sensitive towards others' needs. Thus, we suggest that entrepreneurs are more likely to expand their care orientation to out-group members when people are existentially empowered in society. Moreover, emancipative values, which constitute the spirit of the human empowerment process, give priority to tolerance, solidarity, and 
inclusion, thus making individuals more sensitive towards others' welfare (Welzel 2013). This is then reflected in entrepreneurs' intentions to more willingly contribute to social well-being. Further, our study suggests that a country's prevalence of social movement activity positively enhances prosociality in business. When emancipative values are strong, people raise their voices to achieve emancipatory goals, and this is reflected in the business world. Since the 1980s, a growing number of people sign petitions against particular business and commercial activities, boycott products and services of socially irresponsible firms, and even demonstrate against companies that harm people and environment (Klein et al. 2004). It is now essential for all businesses, including young ventures led by entrepreneurs, to act responsibly towards environment and society (Fassin et al. 2011; Hörisch et al. 2017; Ramus et al. 2018). Our results also suggest that civic entitlements positively impact individuals' chosen level of social orientation for their business. Comprehensibly, a regulation that protects worker and participation rights should enhance the social orientation in doing business. If labor unions and employees are allowed to engage in a variety of business-related decisions, power and wealth within firms can be more distributed, thereby increasingly the probability of achieving social goals (Dawkins 2010). Regulations aimed at providing security, property protection, and low corruption might also lift entrepreneurs' willingness to be more engaged in social innovations (Estrin et al. 2013, 2016). Finally, we provide evidence that the joint effect is much stronger than any single effect of the human empowerment forces, which indicates that the forces of human empowerment complement each other and jointly promote social value creation. In sum, our results complement the debate on the contextual drivers of social entrepreneurship by confirming previous findings that supportive institutional conditions explain prosociality in business.

Moreover, we argue that a focus on female entrepreneurs is essential to fully leverage the potential of social entrepreneurial activity. Women display an affinity towards prosociality - whether due to culture or nature, scientists are not yet sure. Consistent with previous research on values (e.g., Schwartz and Rubel-Lifschitz 2009), we report evidence that women pursue and express their care orientation towards their in-group members more strongly in more emancipatory climates. Since female entrepreneurs in more emancipatory climates are better able to live out their prosocial values, human empowerment strengthens the gender effect on social value creation goals. Previous research highlights the lack of theoretical contributions for helping better understand patterns in social entrepreneurship (Bacq and Eddleston 2018; Cater et al. 2017; Dey and Lehner 2017; Fowler et al. 2017). There is also still a research gap in terms of the impact of contextual variables on female entrepreneurs' value creation goals (Hechavarría et al. 2017) and how environmental conditions moderate the influence of individual-level variables, such as gender, on social entrepreneurship (Stephan et al. 2015). We develop a comprehensive theoretical and conceptual model which incorporates country-level conditions under which women entrepreneurs are even stronger willing to pursue social goals with their businesses. Further, we present new evidence that extends the dominant culture component to a variety of individual, cultural, and institutional factors which moderate the effect of gender on social value creation goals, as we show that woman entrepreneurs' commitment to enhance their venture's social value is an outcome of advantageous conditions.

\section{Implications}

Our study offers both theoretical and practical implications. From a theoretical perspective, the human empowerment framework offers a new insight of how the rising prosociality has increasingly become a mainstream business activity. Businesses' growing willingness to improve social wellbeing and to reduce negative externalities beyond the statutory minimum requirements can be explained against the background of a societal transformation towards humanitarian principles. The empowerment process is not yet complete as younger generations place stronger emphasis on emancipative values than older generations (Welzel 2013), thus continuing to drive prosociality. Given the worldwide trend of a growing number of people relocating from rural, often more traditional areas, to metropolitan cities with greater stocks of action resources in terms of incomes and educational opportunities, we expect further changes in society's emancipative values which will, in turn, further lift the prosociality in the business world. Social responsibility will become even more important and a mainstream of future society. Notably, this shift will probably also imply that ethics and social responsibility become increasingly profitable. If an increasing number of stakeholders focus on businesses' prosociality, business-driven engagement for social issues becomes beneficial for businesses and people (Pless and Maak 2009). Thus, socially responsible actions will be seen as a way to achieve competitive advantage and superior performance (Husted and Allen 2000).

Prosociality in business will also increase due to the strong influence that organizations from more emancipatory climates have on economic and social structures in less economically developed (and less emancipative) societies. Research documents how strong Western businesses positively influence social responsibility policies in developing societies (e.g., Beckman et al. 2009). Western businesses must retain their social licenses to operate in their sales markets, with the positive side effect of offering action resources 
and transferring emancipative values to other regions where these emancipative forces are less pronounced.

Our study also extends the literature in business ethics on the common good as phenomenon including its origins (Argandoña 1998; Melé 2009; Meynhardt and Gomez 2016). The rationale of our human empowerment framework relates to the question of how individuals personally define the common good. The common good is conflated with the well-being of individuals within a public. The public can have different levels of inclusion, ranging from low-inclusive levels such as family, friendship, or work unit, to high-inclusive levels such as the world which are impersonal. In less empowered societies, people tend to have a particularistic orientation towards the common good, thus focusing more on the well-being of a low-inclusive level where in-group boundaries are strong. People who are empowered existentially, psychologically, and institutionally are more likely to contribute to the welfare of all individuals and thus of all humanity. In other words, people follow a universalistic common good orientation which accounts for individual thriving and the well-being of all individuals. This moral universalism is then reflected in form of social responsibility in the business world when business leaders "act as agents of world benefit" (Pless and Maak 2009, p. 60).

In addition, we contribute to the descriptive or empirical business ethics, which strives to understand why individuals and organizations make decisions and behave in particular ways (Blowfield and Murray 2014; Loe et al. 2000). Descriptive business ethics is concerned with explaining, measuring, and predicting business people's decision making, intentions, and behaviors, and operates at the crossroads of a wider range of disciplines that includes psychology, organizational behavior, sociology, anthropology, political economy, and international relations, thereby analyzing the complexity of an individual's embeddedness in environmental structures (Buckley 2013). This study adds to the descriptive business ethics literature by examining how environmental conditions influence individuals' willingness to strengthen the common good. By analyzing how both individual and environmental conditions shape alone and through their interplay individuals' willingness to contribute to the common good, this study seeks to provide a deeper understanding of the relationships between individuals, environments, and the common good.

Our findings reveal that policy makers should strengthen the abundance of empowering resources for women to fully leverage the potential of social entrepreneurship. With respect to individual assets, a functioning welfare system, which provides comprehensive supports and benefits for people, helps ensuring the means and capabilities that entrepreneurs allow a social orientation in doing business. This is especially true for female social entrepreneurs who face double constraints, e.g., funding as social entrepreneurs and women entrepreneurs (Lumpkin et al. 2013). As previous research emphasized, the primary funding sources of social businesses are the individual entrepreneurs and his/her family and friends (Terjesen et al. 2016). Government programs that provide financial support and relevant knowledge could therefore facilitate performing entrepreneurial activities and thereby strengthening a social orientation. Public sector expenditure exerts a strong influence on a country's level of social entrepreneurial activity (Hoogendoorn 2016). Our findings indicate that policy makers should consider both informal and formal institutions when thinking of policy decisions to promote social outcomes in business activity (Stephan et al. 2015). Active government programs, law enforcement, strong worker, and participation rights will help foster the creation of social value in ventures.

Furthermore, we show that strong institutional settings enhance the willingness of entrepreneurs, especially women, to follow social goals in doing business. Our results indicate that women entrepreneurs then pursue socially oriented business practices when a country's cultural and institutional conditions are consistent with the aims of social entrepreneurial activity. Our finding confirm a gendered "institutional support" perspective by showing that favorable institutional circumstances are more important for women entrepreneurs' social orientation, compared to men. Finally, we show that the emancipative forces of human empowerment are complementary and thus develop their impact in combination on social venturing goals. In fact, we find empirical evidence that the combined effect of the human empowerment components is strongest.

\section{Limitations and Future Research}

Our study is not without limitations which represent avenues for future research. First, even if one strength of our study is that we draw on a rich multi-country dataset which enables to apply multilevel modeling, the number of countries is still limited. As a result, second-level standard errors should be interpreted cautiously. Future research should utilize data from more countries to explore potential linkages highlighted in our study. Second, our dataset is crosssectional in nature, thereby raising concerns about reverse causality. Indeed, there is significant reason to believe that social entrepreneurship positively affect the abundance of individual, cultural, and institutional resources. Nevertheless, we think that our research design weakens concerns about reverse causality since we mainly use lagged data for our country-level moderators and specify a complex model with moderating effects. We encourage future researchers to use longitudinal designs to investigate the drivers of prosociality in business. Given social enterprises' propensity to mission drift (Ramus and Vaccaro 2017), this line of enquiry could also examine differences in potential mission drift over 
time. Longitudinal data could also enable scholars to examine how shifts in country's emancipative forces influence the prevalence of prosociality in business. Moreover, if social entrepreneurship is itself a force that can affect emancipative forces, future research could investigate how social entrepreneurs actually stimulate and encourage changes in living standards, values, or laws (Datta and Gailey 2012; Boulouta and Pitelis 2014). Furthermore, there is reason to believe that social entrepreneurship itself is a type of social movement activity (Lee et al. 2018). With respect to the corporate citizenship literature, social entrepreneurs may be considered accepted players in the arena of civic entitlements (Matten et al. 2003). Thus, future research could examine the relationships between human empowerment, social entrepreneurship, and the corporate citizenship literature. Third, we measure entrepreneurs' social orientation, not their social behavior. The GEM dataset does not measure whether or how entrepreneurs capture social value for their societies. Future research should therefore seek to capture ventures' actual social value creation goals and explore gender differences. Fourth, our measure is ipsative, which assumes a trade-off between social value creation goals and economic social value creation goals; however, social entrepreneurs seek efficient means to achieve their social and economic missions (Harris et al. 2009) — commonly understood as integrated or shared value creation (Visser and Kymal 2015). Doing well by doing good is increasingly evaluated as a win-win strategy since social business activities can make a firm more profitable (Porter and Kramer 2011). Thus, future work should further examine both tradeoffs and congruency between economic and prosocial value sets. Fifth, a striking aspect of our assessment is that nascent entrepreneurs appear to have stronger intentions for social value creation. This is in line with Hörisch et al.'s (2018) finding that nascent entrepreneurs are, compared to established entrepreneurs, more environmentally oriented with their ventures. Tracking nascent entrepreneurs over time can help us more thoroughly understand how value creation and value capture tensions might lead to mission drift manifestations in start-ups as they age through different stages using methods like as ethnographies or qualitative case work. Finally, our research engages in strategic essentialism to investigate empirical differences of biological sex in social entrepreneurship, and then extrapolates to understand the phenomena of gender. Scholars engage in this "strategic essentialism" to temporarily essentialize a group in order to reclaim that group's identity (Calás and Smircich 1999). Essentialism is frequently criticized by constructivists who claim that essential identities are not valid as everything is socially constructed. This constructivist ontology focuses on understanding subjective opinion such that a property only has meaning only within certain times and cultures. Individuals and groups "need to act, as if there were" these identities (Barker 2004, p. 189) hence strategic essentialism captures how ordinary people represent categories (Halam et al. 2000; Prentice and Miller 2006). Essentialism and constructivism both explore the degree to which findings meaningfully reflect social phenomenon (Cupchik 2001), albeit with different interpretations. In the case of gender, essentialism's focus on biological sex may be more appropriate for certain research designs; however, constructivism's description of the social concept of gender might be more appropriate (Ortiz 1993). Future researchers could explore tensions associated with the juxtaposition of sex as objective fact and gender as a subjective opinion. This line of enquiry might lead to new questions regarding how female commercial entrepreneurs act in a society characterized by strong empowerment. The use of both constructivist and positivist approaches can "challenge simple, totalizing descriptions of identity, leading to more and more specific, complex, and subtle conceptions of community" (Ortiz 1993, p. 1856). In sum, we utilize strategic essentialism to draw attention to statistically significant effects of the human empowerment forces on the socially meaningful process of social entrepreneurship. We also demonstrate how biological sex, as an objective fact, amplifies prosocial motivations, and should further examine in descriptive depth the multi-faceted phenomenon of prosocial venturing by unpacking an entrepreneur's self-concept of gender identity, which is an intra-subjective opinion.

To conclude, our findings provide support for our theorized human empowerment framework. We show that the four components of our framework not only elevate prosociality, but also amplify the positive gender effect on prosociality in doing business. We hope then that this human empowerment framework can provide a catalyst for further studies trying to better understand why businesses increasingly undertake prosocial activities.

Acknowledgements The authors would like to thank the guest editors and three anonymous reviewers for their very helpful comments and suggestions.

\section{Compliance with Ethical Standards}

Conflict of interest All four co-authors declare that they have no conflicts of interest.

Ethical Approval All procedures performed in studies involving human participants were in accordance with the ethical standards of the institutional and/or national research committee and with the 1964 Helsinki declaration and its later amendments or comparable ethical standards. Informed consent was obtained from all individual participants included in the study, from the respective datasets.

Open Access This article is distributed under the terms of the Creative Commons Attribution 4.0 International License (http://creativeco mmons.org/licenses/by/4.0/), which permits unrestricted use, distribution, and reproduction in any medium, provided you give appropriate credit to the original author(s) and the source, provide a link to the Creative Commons license, and indicate if changes were made. 


\section{References}

Acemoglu, D., Johnson, S., \& Robinson, J. A. (2001). The colonial origins of comparative development: An empirical investigation. American Economic Review, 91(5), 1369-1401.

Alexander, A. C., \& Welzel, C. (2011). Islam and patriarchy: How robust is Muslim support for patriarchal values? International Review of Sociology, 21(2), 249-276.

Álvarez, C., Urbano, D., \& Amorós, J. E. (2014). GEM research: Achievements and challenges. Small Business Economics, 42(3), 445-465.

Argandoña, A. (1998). The stakeholder theory and the common good. Journal of Business Ethics, 17(9/10), 1093-1102.

Bacq, S., \& Eddleston, K. A. (2018). A resource-based view of social entrepreneurship: How stewardship culture benefits scale of social impact. Journal of Business Ethics, 152(3), 589-611.

Balabanis, G. (2013). Surrogate boycotts against multinational corporations: Consumers' choice of boycott targets. British Journal of Management, 24(4), 515-531.

Baldwin, R. (2016). The great convergence. Cambridge: Harvard University Press.

Banerjee, S. B. (2008). Corporate social responsibility: The good, the bad and the ugly. Critical Sociology, 34(1), 51-79.

Barker, C. (2004). The Sage dictionary of cultural studies. Thousand Oaks: Pine Forge: Sage.

Beckman, T., Colwell, A., \& Cunningham, P. H. (2009). The emergence of corporate social responsibility in Chile: The importance of authenticity and social networks. Journal of Business Ethics, 86, 191-206.

Blowfield, M., \& Murray, A. (2014). Corporate responsibility. Oxford: Oxford University Press.

Bosma, N. (2013). The global entrepreneurship monitor (GEM) and its impact on entrepreneurship research. Foundations and Trends in Entrepreneurship, 9(2), 1-85.

Bosma, N., Schøtt, T., Terjesen, S. A., \& Kew, P. (2016). Global entrepreneurship monitor 2015 to 2016: Special report on social entrepreneurship. Global Entrepreneurship Research Association. Retrieved from http://www.gemconsortium.org.

Boulouta, I., \& Pitelis, C. N. (2014). Who needs CSR? The impact of corporate social responsibility on national competitiveness. Journal of Business Ethics, 119(3), 349-364.

Bowen, H. P., \& de Clercq, D. (2008). Institutional context and the allocation of entrepreneurial effort. Journal of International Business Studies, 39(4), 747-767.

Brammer, S., Jackson, G., \& Matten, D. (2012). Corporate social responsibility and institutional theory: New perspectives on private governance. Socio-Economic Review, 10(1), 3-28.

Brieger, S. A., \& De Clercq, D. (2018). Entrepreneurs' individual-level resources and social value creation goals: The moderating role of cultural context. International Journal of Entrepreneurial Behavior \& Research. https://doi.org/10.1108/IJEBR-12-2017-0503.

Brieger, S. A., Francoeur, C., Welzel, C., \& Ben-Amar, W. (2017). Empowering women: The role of emancipative forces in board gender diversity. Journal of Business Ethics. https://doi. org/10.1007/s10551-017-3489-3.

Buckley, M. (2013). A constructivist approach to business ethics. Journal of Business Ethics, 117(4), 695-706.

Calás, M. B., \& Smircich, L. (1999). Past postmodernism? Reflections and tentative directions. Academy of Management Review, 24(4), 649-672.

Cater, J. J., Collins, L. A., \& Beal, B. D. (2017). Ethics, faith, and profit: Exploring the motives of the US fair trade social entrepreneurs. Journal of Business Ethics, 146(1), 185-201.

Costa, P. Jr., Terracciano, A., \& McCrae, R. R. (2001). Gender differences in personality traits across cultures: Robust and surprising findings. Journal of Personality and Social Psychology, 81(2), $322-331$.

Cupchik, G. (2001). Constructivist realism: An ontology that encompasses positivist and constructivist approaches to the social sciences. Forum Qualitative Sozialforschung/Forum: Qualitative Social Research, 2(1), 1-11.

Datta, P. B., \& Gailey, R. (2012). Empowering women through social entrepreneurship: Case study of a women's cooperative in India. Entrepreneurship Theory and Practice, 36(3), 569-587.

Dawkins, C. (2010). Beyond wages and working conditions: A conceptualization of labor union social responsibility. Journal of Business Ethics, 95(1), 129-143.

Deaton, A. (2013). The great escape: Health, wealth, and the origins of inequality. Princeton: Princeton University Press.

Dey, P., \& Lehner, O. (2017). Registering ideology in the creation of social entrepreneurs: Intermediary organizations, 'ideal subject,' and the promise of enjoyment. Journal of Business Ethics, 142(4), 753-767.

Eagly, A. H. (2009). The his and hers of prosocial behavior: An examination of the social psychology of gender. American Psychologist, 64(8), 644-658.

Eagly, A. H., \& Wood, W. (2011). Social role theory. In: Handbook of theories in social psychology, 2 (pp. 458-476). Thousand Oaks: SAGE Publications.

Edwards, I. R., \& Shipp, A. I. (2007). The relationship between personenvironment fit and outcomes: An integrative. In: Perspectives on organizational fit (pp. 209-258). San Francisco: Jossey-Bass.

Edwards, J. R., Cable, D. M., Williamson, I. O., Lambert, L. S., \& Shipp, A. J. (2006). The phenomenology of fit: Linking the person and environment to the subjective experience of personenvironment fit. Journal of Applied Psychology, 91(4), 802-827.

Estrin, S., Mickiewicz, T., \& Stephan, U. (2013). Entrepreneurship, social capital, and institutions: Social and commercial entrepreneurship across nations. Entrepreneurship Theory and Practice, 37(3), 479-504.

Estrin, S., Mickiewicz, T., \& Stephan, U. (2016). Human capital in social and commercial entrepreneurship. Journal of Business Venturing, 31(4), 449-467.

Fassin, Y., Van Rossem, A., \& Buelens, M. (2011). Small-business owner-managers' perceptions of business ethics and CSR-related concepts. Journal of Business Ethics, 98(3), 425-453.

Fowler, E. A., Coffey, B. S., \& Dixon-Fowler, H. R. (2017). Transforming good intentions into social impact: A case on the creation and evolution of a social enterprise. Journal of Business Ethics. https ://doi.org/10.1007/s10551-017-3754-5.

Francescato, D., Mebane, M. E., \& Vecchione, M. (2017). Gender differences in personal values of national and local Italian politicians, activists and voters. International Journal of Psychology, $52(5), 406-414$.

Friedman, B. M. (2010). The moral consequences of economic growth. New York: Vintage.

Gelfand, M. J., Raver, J. L., Nishii, L., Leslie, L. M., Lun, J., Lim, B. C., et al. (2011). Differences between tight and loose cultures: A 33-nation study. Science, 332(6033), 1100-1104.

Griffiths, M. D., Gundry, L. K., \& Kickul, J. R. (2013). The sociopolitical, economic, and cultural determinants of social entrepreneurship activity: An empirical examination. Journal of Small Business and Enterprise Development, 20(2), 341-357.

Halam, N., Rothschild, L., \& Ernst., D. (2000). Essentialist beliefs about social categories. British Journal of Social Psychology, 39, 113-127.

Harris, J. D., Sapienza, H. J., \& Bowie, N. E. (2009). Ethics and entrepreneurship. Journal of Business Venturing, 24(5), 407-418.

Hechavarría, D. M., Ingram, A., Justo, R., \& Terjesen, S. (2012). Are women more likely to pursue social and environmental entrepreneurship? In: Global women's entrepreneurship research: 
Diverse settings, questions and approaches (pp. 135-151). Cheltenham: Edward Elgar.

Hechavarría, D. M., Terjesen, S. A., Ingram, A. E., Renko, M., Justo, R., \& Elam, A. (2017). Taking care of business: The impact of culture and gender on entrepreneurs' blended value creation goals. Small Business Economics, 48(1), 225-257.

Hoogendoorn, B. (2016). The prevalence and determinants of social entrepreneurship at the macro level. Journal of Small Business Management, 54(S1), 278-296.

Hörisch, J., Kollat, J., \& Brieger, S. A. (2017). What influences environmental entrepreneurship? A multilevel analysis of the determinants of entrepreneurs' environmental orientation. Small Business Economics, 48(1), 47-69.

Hörisch, J., Kollat, J., \& Brieger, S. A. (2018). Environmental orientation among nascent and established entrepreneurs: An empirical analysis of differences and their causes. International Journal of Entrepreneurial Venturing.

Hox, J. (2010). Multilevel analysis: Techniques and applications. New York: Routledge.

Hudson, V. M., Ballif-Spanvill, B., Caprioli, M., \& Emmett, C. F. (2014). Sex and world peace. New York: Columbia University Press.

Husted, B. W., \& Allen, D. B. (2000). Is it ethical to use ethics as strategy? Journal of Business Ethics, 27(1-2), 21-31.

ILO (2013a). Social dimensions of free trade agreements. International Labour Organization; International Institute for Labour Studies. - Geneva: ILO.

ILO (2013b). Progress against child labour - Global estimates and trends 2000-2012. International Programme on the Elimination of Child Labour (IPEC). International Labour Organization; International Institute for Labour Studies. Geneva: ILO.

ILO. (2017). Global estimates of child labour: Results and trends, 2012-2016. In International Labour Organization; International Institute for Labour Studies. Geneva: ILO.

Inglehart, R., \& Norris, P. (2003). Rising tide: Gender equality and cultural change around the world. Cambridge: Cambridge University Press.

Inglehart, R., \& Welzel, C. (2005). Modernization, cultural change, and democracy: The human development sequence. Cambridge: Cambridge University Press.

Ioannou, I., \& Serafeim, G. (2012). What drives corporate social performance? The role of nation-level institutions. Journal of International Business Studies, 43(9), 834-864.

Jaffee, S., \& Hyde, J. S. (2000). Gender differences in moral orientation: A meta-analysis. Psychological Bulletin, 126(5), 703-726.

John, A., \& Klein, J. (2003). The boycott puzzle: Consumer motivations for purchase sacrifice. Management Science, 49(9), $1196-1209$.

Jones, T. M., \& Gautschi, F. H. (1988). Will the ethics of business change? A survey of future executives. Journal of Business Ethics, 7(4), 231-248.

Kickul, J., Janssen-Selvadurai, C., \& Griffiths, M. D. (2012). A blended value framework for educating the next cadre of social entrepreneurs. Academy of Management Learning \& Education, 11(3), 479-493.

Kinderman, D. (2012). 'Free us up so we can be responsible!' The coevolution of corporate social responsibility and neo-liberalism in the UK, 1977-2010. Socio-Economic Review, 10(1), 29-57.

Klasen, S. (2002). Low schooling for girls, slower growth for all? Cross-country evidence on the effect of gender inequality in education on economic development. The World Bank Economic Review, 16(3), 345-373.

Klein, J. G., Smith, N. C., \& John, A. (2004). Why we boycott: Consumer motivations for boycott participation. Journal of Marketing, 68(3), 92-109.
Lee, M., Ramus, T., \& Vaccaro, A. (2018). From protest to product: Strategic frame brokerage in a commercial social movement organization. Academy of Management Journal. https://doi. org/10.5465/amj.2016.0223.

Lepoutre, J., Justo, R., Terjesen, S., \& Bosma, N. (2013). Designing a global standardized methodology for measuring social entrepreneurship activity: The Global Entrepreneurship Monitor social entrepreneurship study. Small Business Economics, 40(3), 693-714.

Locke, R. M., Qin, F., \& Brause, A. (2007). Does monitoring improve labor standards? Lessons from Nike. ILR Review, 61(1), 3-31.

Loe, T. W., Ferrell, L., \& Mansfield, P. (2000). A review of empirical studies assessing ethical decision making in business. Journal of Business Ethics, 25(3), 185-204.

Lumpkin, G. T., Moss, T. W., Gras, D. M., Kato, S., \& Amezcua, A. S. (2013). Entrepreneurial processes in social contexts: How are they different, if at all? Small Business Economics, 40(3), 761-783.

Matten, D., Crane, A., \& Chapple, W. (2003). Behind the mask: Revealing the true face of corporate citizenship. Journal of Business Ethics, 45(1-2), 109-120.

Melé, D. (2009). Integrating personalism into virtue-based business ethics: The personalist and the common good principles. Journal of Business Ethics, 88(1), 227-244.

Messenger, J. C., Lee, S., \& McCann, D. (2007). Working time around the world: Trends in working hours, laws, and policies in a global comparative perspective: Routledge.

Meynhardt, T., Brieger, S. A., \& Hermann, C. (2018). Organizational public value and employee life satisfaction: The mediating roles of work engagement and organizational citizenship behavior. The International Human Resource Management Journal. https://doi. org/10.1080/09585192.2017.1416653.

Meynhardt, T., \& Gomez, P. (2016). Building blocks for alternative four-dimensional pyramids of corporate social responsibilities. Business \& Society. https://doi.org/10.1177/0007650316650444.

Montgomery, A. W., Dacin, P. A., \& Dacin, M. T. (2012). Collective social entrepreneurship: Collaboratively shaping social good. Journal of Business Ethics, 111(3), 375-388.

Norberg, J. (2016). Progress: Ten reasons to look forward to the future. London: Oneworld Publications.

North, D. C. (1991). Institutions. Journal of Economic Perspectives, $5(1), 97-112$.

Ortiz, D. R. (1993). Creating controversy: Essentialism and constructivism and the politics of gay identity. Virginia Law Review, 79, $1833-1857$.

Peels, R., Echeverria, M., Aissi, E., J., \& Schneider, A. (2016). Corporate social responsibility in international trade and investment agreements: Implications for states, business and workers. ILO Research Paper, 13, 1-28.

Pless, N., \& Maak, T. (2009). Responsible leaders as agents of world benefit: Learnings from "Project Ulysses". Journal of Business Ethics, 85(S1), 59-71.

Porter, M. E., \& Kramer, M. R. (2011). The big idea: Creating shared value. Harvard Business Review, 89(1-2), 62-77.

Prentice, D. A., \& Miller, D. T. (2006). Essentializing differences between women and men. Psychological Science, 17(2), 129-135.

Ramus, T., La Cara, B., Vaccaro, A., \& Brusoni, S. (2018). Social or commercial? Innovation strategies in social enterprises at times of turbulence. Business Ethics Quarterly. https://doi.org/10.1017/ beq. 2017.55 .

Ramus, T., \& Vaccaro, A. (2017). Stakeholders matter: How social enterprises address mission drift. Journal of Business Ethics, 143(2), 307-322.

Reynolds, P., Bosma, N., Autio, E., Hunt, S., de Bono, N., Servais, I., Lopez-Garcia, P., \& Chin, N. (2005). Global Entrepreneurship 
Monitor: Data collection design and implementation 1998-2003. Small Business Economics, 24(3), 205-231.

Rokeach, M. (1968). Beliefs, attitudes, and values: A theory of organization and change. San Francisco: Jossey-Bass.

Rousseau, J.-J. (1920). The social contract and discourses. London: JM Dent \& Sons.

Sachs, J. D. (2015). The age of sustainable development. New York: Columbia University Press.

Santos, F. M. (2012). A positive theory of social entrepreneurship. Journal of Business Ethics, 111(3), 335-351.

Scherer, A. G., \& Palazzo, G. (2011). The new political role of business in a globalized world: A review of a new perspective on CSR and its implications for the firm, governance, and democracy. Journal of Management Studies, 48(4), 899-931.

Schneider, B. (2001). Fits about fit. Applied Psychology, 50(1), 141-152.

Schwartz, S. H., \& Rubel, T. (2005). Sex differences in value priorities: Cross-cultural and multimethod studies. Journal of Personality and Social Psychology, 89(6), 1010-1028.

Schwartz, S. H., \& Rubel-Lifschitz, T. (2009). Cross-national variation in the size of sex differences in values: Effects of gender equality. Journal of Personality and Social Psychology, 97(1), 171-185.

Sen, A. (2001). Development as freedom. Oxford: Oxford University Press.

Stephan, U., Uhlaner, L. M., \& Stride, C. (2015). Institutions and social entrepreneurship: The role of institutional voids, institutional support, and institutional configurations. Journal of International Business Studies, 46(3), 308-331.

Terjesen, S., Bosma, N., \& Stam, E. (2016). Advancing public policy for high-growth, female, and social entrepreneurs. Public Administration Review, 76(2), 230-239.
Themudo, N. S. (2009). Gender and the nonprofit sector. Nonprofit and Voluntary Sector Quarterly, 38(4), 663-683.

Triandis, H. C. (1995). Individualism and collectivism. Boulder: Westview Press.

Van Liere, K. D., \& Dunlap, R. E. (1980). The social bases of environmental concern: A review of hypotheses, explanations and empirical evidence. Public Opinion Quarterly, 44(2), 181-197.

Vermeir, I., \& Verbeke, W. (2006). Sustainable food consumption: Exploring the consumer "attitude-behavioral intention" gap. Journal of Agricultural and Environmental Ethics, 19(2), 169-194.

Visser, W., \& Kymal, C. (2015). Integrated value creation (IVC): Beyond corporate social responsibility (CSR) and creating shared value (CSV). Journal of International Business Ethics, $8(1), 29-43$.

Welzel, C. (2013). Freedom rising: Human empowerment and the quest for emancipation. New York: Cambridge University Press.

Welzel, C., \& Deutsch, F. (2012). Emancipative values and non-violent protest: The importance of 'ecological' effects. British Journal of Political Science, 42(2), 465-479.

Williamson, O. E. (2000). The new institutional economics: Taking stock, looking ahead. Journal of Economic Literature, 38(3), 595-613.

Wood, W., \& Eagly, A. H. (2002). A cross-cultural analysis of the behavior of women and men: Implications for the origins of sex differences. Psychological Bulletin, 128(5), 699-727. 